\title{
「2005 年パキスタン地震特集号」に寄せて \\ Foreword for "The special issue on the 2005 Pakistan Earthquake"
}

\author{
鈴木 康弘 \\ SUZUKI Yasuhiro
}

2005 年 10 月 8 日, パキスタン北部カシミール地 方で M7.6 の地震が発生し, 死者 73,000 人を超える 大災害となった. 地震直後, 震源断層等の地震の 原因に関する情報や，死者を多くした災害の直接 的原因に関する情報がそしく，災害の全体像をつ かむことが容易ではなかった。

このような状況の中で, 日本地理学会の災害対 応委員会は, 災害対応グループのメーリングリス 卜において，震源断層の可能性のある活断層の所 在や，活断層と土砂・地盤災害との関係について の情報交換を行い，また，IKONOS，Quickbird 等 の最新の高解像度衛星画像の観察と議論をネット 上で行った.さらに，2005 年末から 2006 年の初め においては, 地理学・地形学者によるリモートセ ンシング画像の解析や現地調査が相次いで実施さ れ，当初不明だった地震災害の全貌が明らかにな っていった.

それらの成果を受け，2006（平成 18）年 3 月 26 日には日本地理学会春季学術大会において, 公開 特別セッション「2005 年パキスタン地震に地形学 はどのように挑んだのか?ーリモートセンシング から地震断層現地調査一」が日本地理学会災害対 応委員会 (委員長 : 遠藤邦彦, 日本大学) により 主催された。研究者やマスコミ関係者等多くの聴 衆が集まり, 活発な議論が交わされた。

当日の発表は以下の 7 件である.

(1)「2005 年パキスタン地震の発生源となった活断 層の認定」（熊原康博（広島大）・中田 高（広 島工業大））

(2)「衛星画像から地表断層変位を探る」（宇根 寛・熊木洋太（国土地理院））
(3)「SAR 解析による地殼変動量と地震断層の推定」 (藤原 智 - 飛田幹男 - 佐藤 浩 - 小沢慎三郎 . 宇根 寛（国土地理院））

(4)「衛星画像解析による斜面崩壊」（佐藤 浩・ 小荒井 衛・宇根 寛・藤原 智 (国土地理院) )

(5)「2005 年パキスタン地震の地震断層の現地調査」 （金田平太郎・粟田泰夫 (産業技術総合研究所) 堤 浩之（京都大） - 中田 高（広島工業大）） (6)「地す心゙り・斜面崩壊の現地調査」（宮城豊彦 （東北学院大） - 八木浩司（山形大） - 丸井英明 （新潟大）・梅村 順（日大） - 内山庄一郎（防 災科学技術研究所））

(7)「2005 年パキスタン地震の地震断層と家屋被害」 （中田高（広島工業大）・粟田泰夫 - 金田平太 郎（産業技術総合研究所）・堤 浩之（京都大））

本特集号は，このセッションにおいて速報され た調查研究内容のうち, 投稿応募のあった 4 編を

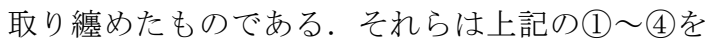
ベースにしたものであり, いずれも地形学的調査 が，地震およびその災害の本質的特徵を明らかに した特筆されるべき内容である。

現地調查を中心とした後半の 3 件についてはこ こには収録されないが，(6)の発表では巨大な地す ベりの成因が議論され, 中越地震における旧山古 志村と同様に, 地す心゙り多発地帯において顕著で あったとされた。また, 臨場感のある地すべりの 目撃証言までが紹介された。 (5)，(7)の発表では, 長さ約 $65 \mathrm{~km}$, 最大変位量約 $9 \mathrm{~m}$ にもおよぶ地震断 層が現地調査により確認されたことが報告され, その結果は, (1)発表による, 地震前に撮影され 
た CORONA 偵察衛星画像による活断層判読結果 と見事に一致した.

セッションにおいても公開された写真 1 は, 今 回の地震災害を典型的に物語る写真として特に注 目を集めた。地す心゙り多発地帯において大規模土 砂災害が再来したように，地震そのものもまた， 活断層が原因となり，近隣においてとくに深刻な 災害をもたらした。自然災害に対する被害軽減に おいて, 地域の自然環境の中に潜む脆弱性に事前 に気づくことの重要性を改めて感じさせる.

図 1 を報告した発表(7)の著者による要旨は次の 通りである.「2005 年パキスタン地震では, 家屋 被害が地震断層近傍の幅狭い地域に集中的に発生 したという特徴がある. 被害の典型例として挙げ られるバラコット旧市街地では, 撓曲崖斜面に位 置していた全ての家屋が倒壊し, 長さ約 $500 \mathrm{~m}$ ・ 幅 100-150 m の狭い範囲で, 死者 1661 名（死亡 率 $85 \%$ ）に達した. また, 既存の断層崖斜面の頂 部では, 引張性の地割れが発生し多くの家屋が倒
壊した。このような家屋被害は, 活断層との密接 な関係を示すもので，「活断層直上」に家を建て ることの危険性を如実に物語るものであった。」

以上に述べたとおり, 本特集号の発刊の第一の 意図は, 地震災害研究における地理学・地形学的 調査の重要性を示すことにある.ここで紹介する 研究内容がなかったら, 地震の全貌の理解は未だ にあり得なかったと言っても過言ではない。また 発刊のもうひとつの意困は, 地域の自然環境の脆 弱性についての理解が, 被害軽減のために如何に 重要であるかを考えることにもある．読者の方々 に，そのことを感じるきっかけにしていただけれ ば幸いである。

なお，本特集号の企画および編集は，災害対応 委員会に設置した特集号編集委員会（委員長：鈴 木康弘，委員：鈴木毅彦・平井幸弘・小口千明） と, E-journal GEO 編集委員会 (委員長 : 岡橋秀典) が合同で行った。

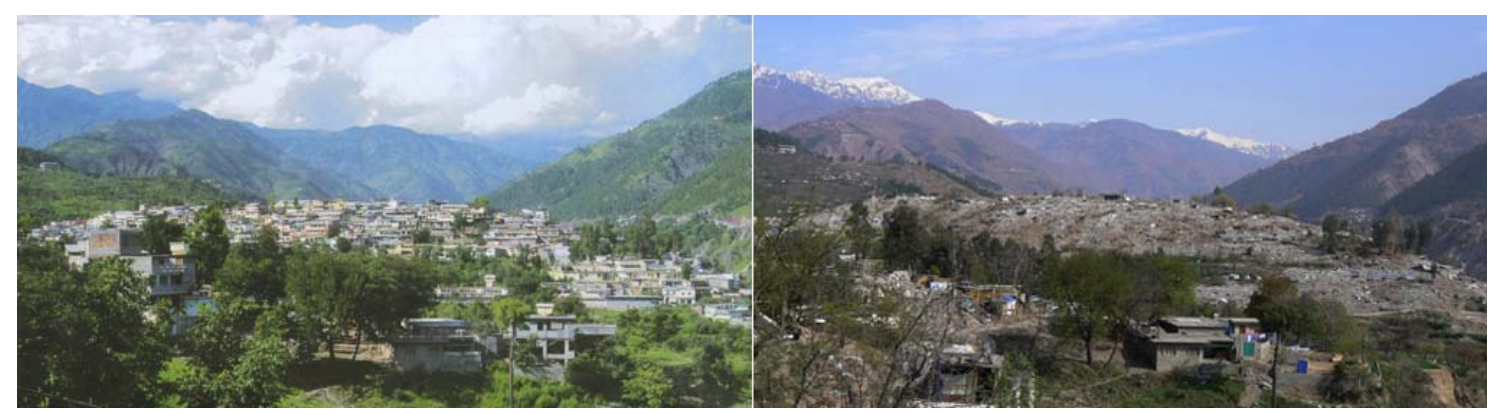

図 1 地震前後の Old Balakot 市街地の写真 左 : A.Rashid 2004 年 7 月撮影, 右：中田 高 2006 年 3 月撮影

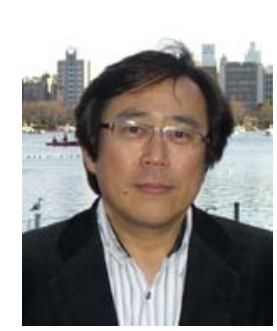

＜著者略歴＞ 鈴木康弘（すずき やすひろ）

日本地理学会災害対応委員会幹事

名古屋大学大学院環境学研究科附属地震火山・防災研究センター教授 